Acta vet. scand. $1986,27,257-266$.

From the Department of Obstetrics and Gynaecology, and Department of Clinical Chemistry, College of Veterinary Medicine, Swedish University of Agricultural Sciences, Uppsala, Sweden.

\title{
LUTEINIZING HORMONE (LH) RESPONSE TO DIFFERENT DOSES OF SYNTHETIC GONADO- TROPIN RELEASING HORMONE (GnRH) IN PREPUBERTAL GILTS
}

\author{
By \\ S. Rojanasthien, A. Kunavongkrit and S. Einarsson
}

\begin{abstract}
ROJANASTHIEN, S., A. KUNAVONGKRIT and S. EINARSSON: Luteinizing hormone $(\mathrm{LH})$ response to different doses of synthetic gonadotropin releasing hormone (GnRH) in prepubertal gilts. Acta. vet. scand. 1986, 27, 257-266. - The object of this investigation was to study luteinizing hormone ( $\mathrm{LH}$ ) response to different doses of synthetic gonadotropin-releasing hormone (GnRH) in prepubertal gilts. Four crossbred prepubertal gilts, 128-134 days old and body weight $57-63 \mathrm{~kg}$, were used in this study. Four dosies, 0. 5, 25 and 125 $\mu \mathrm{g}$, of GnRH were administered via a jugular vein catheter in a latin square design. Each treatment consisted of 3 injections at $90 \mathrm{~min}$ intervals. Frequent blood samples were taken during a period of 90 min before up to $90 \mathrm{~min}$ after treatment. Total $\mathrm{LH}$ responses were measured from post-treatment samples as the area under the curve above base level obtained from pre-treatment samples. A positive relationship between $\mathrm{GnRH}$ dose and $\mathrm{LH}$ release was obtained in all gilts, except for 1 treatment given to a gilt with high plasma level of oestradiol-17 $\beta$ on the day of treatment. This study has demonstrated the responsiveness of the pituitary gland by $\mathrm{LH}$ release to different doses of GnRH in 4.5-month-old prepubertal gilts.
\end{abstract}

pituitary response; LH-RH.

Gonadotropic hormones play important roles in development and function of the gonads. The isolation, identification and purification of gonadotropin-releasing hormone (GnRH) from the porcine hypothalamus was reported by Schally et al. in 1971. Since that time GnRH has been used to study the pituitary response and the subsequent ovarian activity in prepubertal gilts (Chakraborty et al. 1973, Foxcroft et al. 1975, Guthrie 1977, Carpenter \& Anderson 1981, Flemming \& Dailey 1982, Trout et al. 
1984 and Lutz et al. 1985). The pituitary response to GnRH varied with the dose in 9-10-week-old gilts (Foxcroft et al. 1975). The relationship between oestradiol and $\mathrm{LH}$ response to exogenous GnRH had been previously studied. Pomerantz et al. (1975) reported that oestradiol-17 $\beta$ treatment in 7-8-week-old gilts depresses the pituitary response to exogenous GnRH. Also prepubertal gilts approaching their first oestrus with high levels of oestradiol-17 $\beta$ in their peripheral blood did not respond to GnRH with elevated levels of LH (Andersson et al. 1983a).

Different results have been reported concerning the effect of GnRH treatment on follicular development and ovulation in prepubertal gilts. One injection of $500 \mu \mathrm{g}$ GnRH to 160-day-old gilts induced ovulation (1.3 c.l./animal) in 3 out of 6 animals (Guthrie 1977). Andersson et al. (1983a) obtained no ovulation in 6 gilts (141 days old) treated with $250 \mu \mathrm{g}$ GnRH. However, pulsatile injection of GnRH for several days induced ovulation in 1 of 4 gilts (Carpenter \& Anderson 1981) and 3 of 3 gilts (Lutz et al. 1985). The purpose of this study was to determine the LH response to different doses of synthetic GnRH in prepubertal 4.5month-old gilts.

\section{MATERIAL AND METHODS}

Four crossbred prepubertal gilts (Swedish Landrace $\times$ Swedish Yorkshire) were used in this study (no. 31, 32, 33 and 34). They were purchased from a commercial herd and brought to the Department of Obstetrics and Gynaecology 1 week before the start of the experiment. They were 128-134 days old and weighed $57-63 \mathrm{~kg}$ at the beginning of the experiment. The gilts were housed in individual pens throughout the experimental period and fed according to the Swedish breeding stock standard. Oestrous detection was performed twice daily in the presence of a boar throughout the experimental period. One day before the day of the first treatment (day 1) the gilts were examined by mean of laparoscopy (Wildt 1973) for confirmation that the genital tract was intact and that the ovaries only contained small follicles $(\varnothing \leq 6 \mathrm{~mm})$. A jugular vein catheterization was performed after the laparoscopic examination. Laparoscopic examination of the ovarian status was performed twice more (days 6 and 13 of treatment).

Synthetic GnRH (Lutrelef lyofilisate, Ferring, West Germny) was dissolved in physiological saline to the desired concentra- 
tion. Four doses of $0,5,25$ and $125 \mu \mathrm{g} \mathrm{GnRH}$ in $5 \mathrm{ml}$ physiological saline were injected via the jugular vein catheter in a latin square design (Snedecor 1966). The treatment was performed at 3 -day intervals. Each treatment consisted of 3 injections at 90 min intervals.

Daily blood samples were collected at 9.00 a.m. throughout the experimental period. On the day of $\mathrm{GnRH}$ treatment blood samples were collected frequently every $15 \mathrm{~min}$ for $6 \mathrm{~h}$ from 90 min before the first injection until 90 min after the last injection. All blood samples were collected into heparinized tubes, the plasma was removed after centrifugation and stored in plastic tubes at $-20^{\circ} \mathrm{C}$ until radioimmunoassays were performed. The daily samples were analysed for the levels of progesterone (Bosu et al. 1976) and oestradiol-17 $\beta$ (Boilert et al. 1973). The frequently collected samples were analysed for the levels of $\mathrm{LH}$ (Stupnicki \& Madej 1976). The method used for LH analysis has earlier been validated in the porcine species (Kunavongkrit et al. 1983).

The LH base level was defined as the arithmetic mean plus 2 standard deviations of the $\mathrm{LH}$ values from the samples collected before each GnRH treatment. The total $\mathrm{LH}$ response was measured as the area under the curve above base level.

All animals were slaughtered on day 16 of treatment and the reproductive organs were removed and examined macroscopically. The ovaries were fixed in formalin, sectioned and stained by conventional histological methods.

\section{RESULTS}

None of the gilts showed standing oestrus throughout the experimental period, but gilt 32 had a slightly reddish and swollen vulva on days 8 and 9 of treatment. The mean plasma level of $\mathrm{LH}$ of the gilts before $\mathrm{GnRH}$ tretament was $0.96 \pm 0.23$ $\mu \mathrm{g} / \mathrm{l}$ (range $0.68-1.38 \mu \mathrm{g} / \mathrm{l}$ ). A significant elevation of the $\mathrm{LH}$ basal level was observed in $25 \%$ of the pretreatment sampling periods, i.e. $1 \mathrm{LH}$ peak per $4 \mathrm{~h}$. The individual responses to various doses of GnRH treatments for all 4 gilts are shown in Fig. 1. A positive relationship between $\mathrm{GnRH}$ dose and LH release was obtained in each gilt except for $125 \mu \mathrm{g}$ of GnRH treatment of gill 32. The duration of maximum $\mathrm{LH}$ response to $\mathrm{GnRH}$ treatment increased with increasing doses. An example of the 


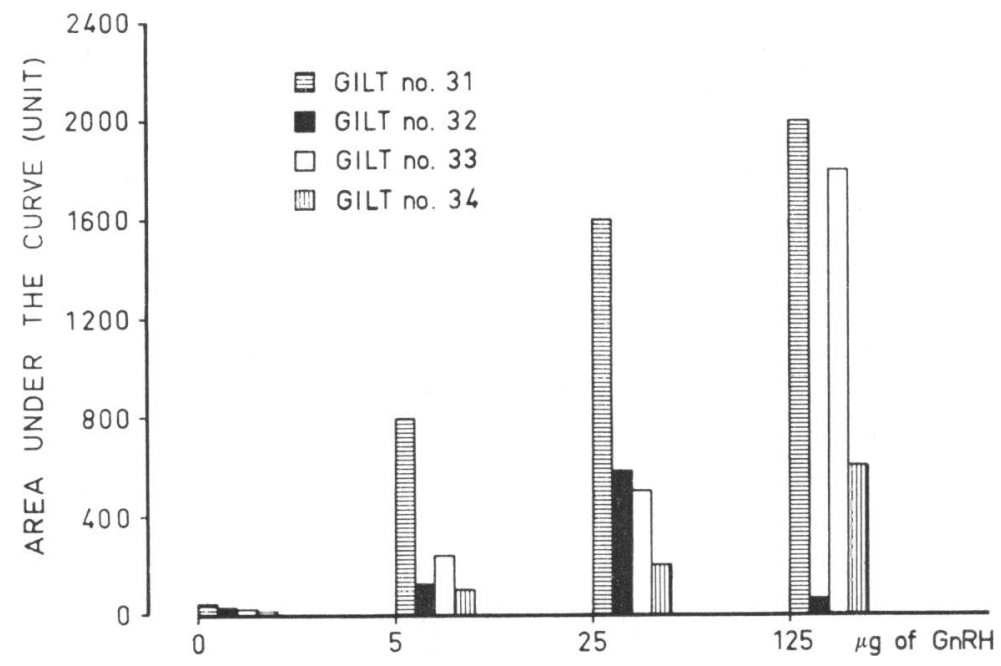

F i g u r e 1. LH response in relation to different doses $(0-125 \mu \mathrm{g})$ of GnRH measured as the area under the curve above base level +2 S.D. in individual gilts.

LH pattern recorded within $6 \mathrm{~h}$ (from $90 \mathrm{~min}$ before the first injection until 90 min after the third injection) of gilt 32 is shown in Fig. 2.

The peripheral plasma levels of oestradiol-17 $\beta$ and progesterone for all gilts are presented in Fig. 3. A small elevation of oestradiol-17 $\beta$ level was found only in gilt 32 during days $5-7$ of treatment. An increasing level of progesterone occurred from day 13 and 7 of treatment in gilts 31 and 32, respectively.

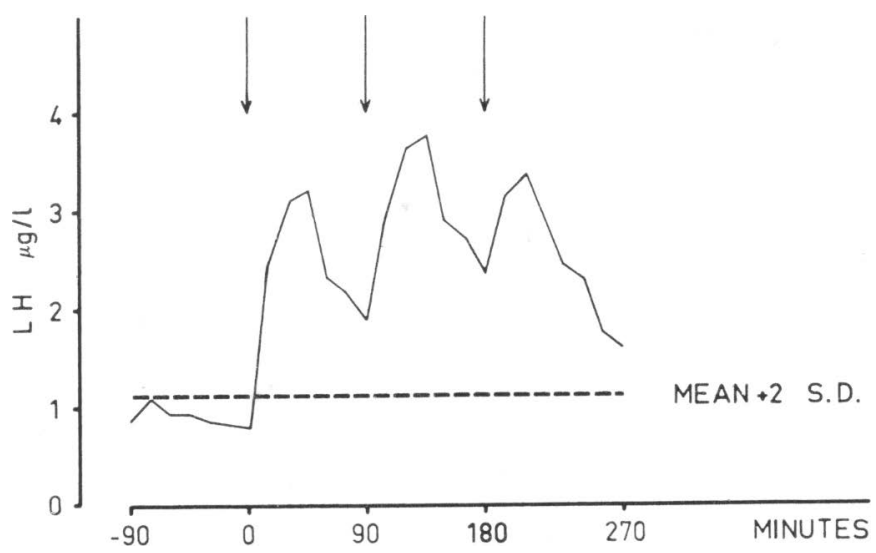

F i g u r e 2. Gilt 32, plasma LH concentrations in relation to the time of treatment (arrows indicate the time of $\mathrm{GnRH}$ injections). 

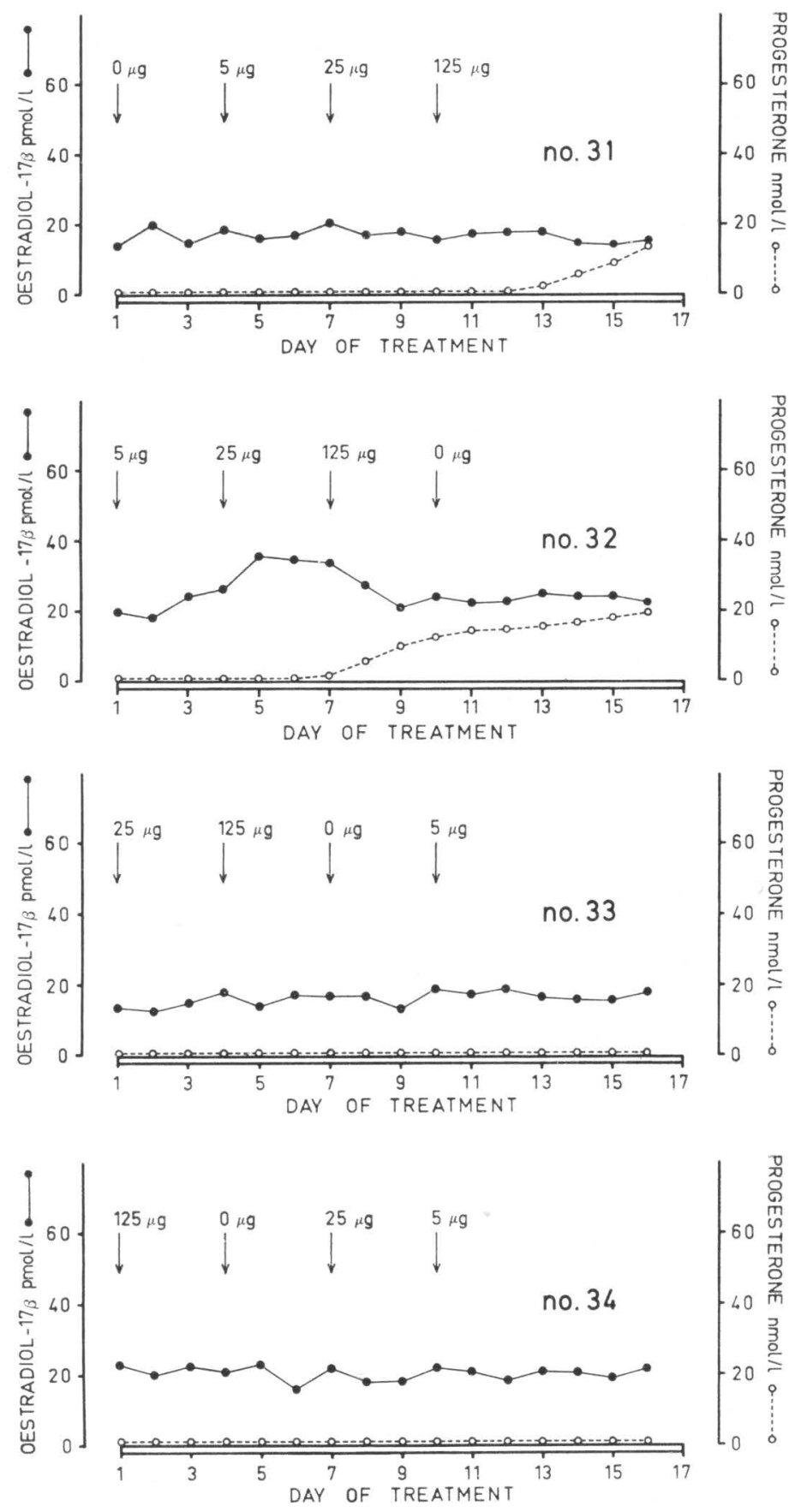

Figure 3. Peripheral plasma concentration of oestradiol-17 $\beta$ $(\mathrm{O}-\mathrm{O})$ and progesterone $(\mathrm{O} \ldots \mathrm{O})$ during the experimental period in 4 gilts (arrows indicate day of $\mathrm{GnRH}$ treatment). 
The results of the laparoscopic examinations and the post mortem examinations are presented in Table 1. At laparoscopic examination on day 6 of treatment gilts 31 and 33 had only small follicles $(\varnothing \leq 6 \mathrm{~mm})$, while gilts 32 and 34 had developed some big follicles $(\varnothing=8-10 \mathrm{~mm})$. The laparoscopic examination performed 3 days after the last treatment (day 13) revealed that gilt 31 had 2 new corpora hemorraghica, 3 follicular cysts $(\varnothing=15-25 \mathrm{~mm})$ and $7 \mathrm{big}$ follicles $(\varnothing=8 \mathrm{~mm})$, gilt $32 \mathrm{had}$ 3 corpora lutea, 4 follicular cysts $(\varnothing=20 \mathrm{~mm})$ and some small follicles, gilt 33 had only 2 big follicles $(\varnothing=10 \mathrm{~mm}$ ) and many small follicles $(\varnothing \leq 6 \mathrm{~mm})$ and gilt 34 had 8 big follicles $(\varnothing=8$ $\mathrm{mm}$ ) and some small follicles $(\varnothing \leq 6 \mathrm{~mm})$.

The results of the post montem examinations of the genital organs correspond well with the laparoscopic findings 3 days earlier.

T a b l e 1. Laparoscopy and post mortem findings in 4 gilts during and after treatment.

\begin{tabular}{|c|c|c|c|}
\hline \multirow[b]{2}{*}{ Gilts } & \multicolumn{2}{|c|}{ Laparoscopic examination finding } & \multirow{2}{*}{$\begin{array}{l}\text { Post mortem finding } \\
\text { day } 16 \text { of treatment }\end{array}$} \\
\hline & day 6 of treatment & day 13 of treatment & \\
\hline RO & many small follicles & 3 follicles $\varnothing 8 \mathrm{~mm}$ & 6 follicles $\varnothing 7 \mathrm{~mm}$ \\
\hline \multirow{8}{*}{31} & & 1 cyst $\varnothing 15 \mathrm{~mm}$ & 1. cyst $\varnothing 15 \mathrm{~mm}$ \\
\hline & many small follicles & 4 follicles $\varnothing 8 \mathrm{~mm}$ & 3 follicles $\varnothing 7-8 \mathrm{~mm}$ \\
\hline & & 2 cysts $\varnothing 18-25 \mathrm{~mm}$ & 1 luteinized cyst $\varnothing 8 \mathrm{~mm}$ \\
\hline & & 2 ovulated follicles & 2 cysts $\varnothing 20,25 \mathrm{~m}$ \\
\hline & & & 2 corpora lutea \\
\hline & 5 follicles $\varnothing 8-10 \mathrm{~mm}$ & some small follicles & 9 follicles $\varnothing 8-10 \mathrm{~mm}$ \\
\hline & many small follicles & 1 cyst $\varnothing 20 \mathrm{~mm}$ & 3 cysts $\varnothing 13-25 \mathrm{~mm}$ \\
\hline & & 1 corpus luteum & 1 corpus luteum \\
\hline \multicolumn{4}{|c|}{ 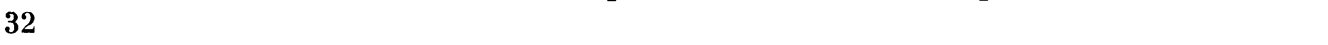 } \\
\hline LO & 5 follicles $\varnothing 7 \mathrm{~mm}$ & some small follicles & 9 follicles $\varnothing 5-8 \mathrm{~mm}$ \\
\hline & many small follicles & 3 cysts $\varnothing 20 \mathrm{~mm}$ & 3 luteinized cysts $\varnothing 20 \mathrm{~mm}$ \\
\hline & & 2 corpora lutea & 2 corpora lutea \\
\hline RO & many small follicles & 2 follicles $\varnothing 10 \mathrm{~mm}$ & many small follicles \\
\hline \multicolumn{4}{|c|}{ many small follicles } \\
\hline LO & many small follicles & many small follicles & many small follicles \\
\hline RO & $\begin{array}{l}4 \text { follicles } \varnothing 8 \mathrm{~mm} \\
\text { some small follicles }\end{array}$ & many small follicles & many small follicles \\
\hline \multicolumn{4}{|c|}{ 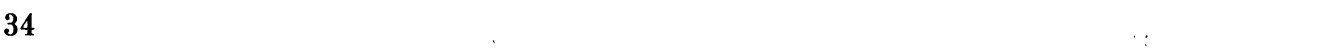 } \\
\hline LO & $\begin{array}{l}2 \text { follicles } \varnothing 7 \mathrm{~mm} \\
\text { some small follicles }\end{array}$ & $\begin{array}{l}8 \text { follicles } \varnothing 7 \mathrm{~mm} \\
\text { some small follicles }\end{array}$ & many small follicles \\
\hline
\end{tabular}

RO: Right ovary.

LO: Left ovary. 


\section{DISCUSSION}

All gilts in this study were brought to the clinic 1 week before the start of the experiment. Oestrous detection and laparoscopic examination for ovarian status were performed before starting the GnRH treatment to confirm that the gilts were prepubertal.

The mean plasma concentration of LH before each treatment of the 4 gilts in the present study was $0.96 \pm 0.23 \mu \mathrm{g} / \mathrm{l}$ (range $0.68-1.38 \mu \mathrm{g} / \mathrm{l}$ ), which is in agreement with previous studies on prepubertal gilts at the same age (Karlbom et al. 1982, Flemming \& Dailey 1982, Lutz et al. 1984). Also the numbers of LH peaks measured are in close accordance with earlier published results (e.g. Andersson et al. $1983 \mathrm{~b}$ and Lutz et al. 1984).

The present results demonstrate the ability of the pituitary gland in the prepubertal gilt (4.5 months of age) to respond to the repeated treatments (90 min intervals) with exogenous synthetic GnRH by releasing of $\mathrm{LH}$ into the blood circulation. The result is in agreement with earlier studies in prepubertal gilts (Chakraborty et al. 1973, Carpenter \& Anderson 1981, Lutz et al. 1985). In the present study both the magnitude of $\mathrm{LH}$ response and the latency following GnRH injection, at which maximal responses were observed, increased with increasing dose of GnRH treatment, which is in close accordance with the finding of Foxcroft et al. (1975).

No $\mathrm{LH}$ response to $125 \mu \mathrm{g}$ of $\mathrm{GnRH}$ was detected in gilt 32, which might be explained by the high level of oestradiol-17 $\beta$ measured in the peripheral blood in this gilt at the time of this treatment. This result is in accordance with an earlier observation by Andersson et al. (1983a), who injected $250 \mu \mathrm{g}$ of $\mathrm{GnRH}$ into gilts during the follicular phase and found no response of the LH. During the follicular phase in pigs the plasma levels of LH are low, concomittantly with rising levels of oestradiol-17 $\beta$ (Karlbom et al. 1982, Andersson et al. 1984).

Ovulations occurred in 2 gilts (nos. 31, 32) without standing oestrus. This phenomenon also occurs in a few pubertal gilts ovulating spontaneousily (Andersson et al. 1982). In gilt 31 , the peripheral plasma level of oestradiol-17 $\beta$ was lower than the detecting limit of the assay throughout the experimental period. This might be due to a low oestrogen production in the ovaries and explain why no external oestrous symptoms at all were detected in this gilt. In gilt 32 plasma levels of oestradiol-17 $\beta$ above 
the detecting limit of the assay were observed on 3 successive days of observation without standing oestrus. This is in agreement with observations made by Dial et al. (1983). They found that some prepubertal gilts (135-150 days of age) did not show any oestrous symptoms after treatment with low doses of oestradiol benzoate despite an oestradiol peak in the blood circulation.

In conclusion, this study has demonstrated the responsiveness of the pituitary gland by LH release to different doses of synthetic GnRH treatment in prepubertal gilts 4.5 months of age.

\section{ACKNOWLEDGEMENTS}

This work was supported by grants from the Swedish Council for Forestry and Agricultural Research. A scholarship awarded to S. Rojanasthien by the Swedish International Development Authority (SIDA) is also acknowledged.

\section{REFERENCES}

Andersson, A.-M., S. Einarsson \& I. Karlbom: A study on the occurrence of silent and/or anovulatory heats in prepubertal gilts. 7th International Pig Vet. Soc. Congr., Mexico City, July 26-31 1982, p. 236.

Andersson, A.-M., S. Einarsson \& L.-E. Edqvist: Treatment with gonadotropin releasing hormone in prepubertal gilts at two different ages. Acta vet. scand. 1983a, 24, 446-455.

Andersson, A.-M., S. Einarsson \& L.-E. Edqvist: Prepubertal LH, oestradiol-17 $\beta$ and progesterone pattern in gilts. Zbl. Vet. Med. A, $1983 \mathrm{~b}, 30,438-446$.

Andersson, A.-M., S. Einarsson, L.-E. Edqvist \& N. Lundeheim: Endocrine pattern and external oestrous symptoms at second and fourth oestrus in gilts. Anim. Reprod. Sci. 1984, 6, 301-310.

Boilert, B., L.-E. Edqvist, E. D. B. Johansson, D. Lindberg \& K. Martinsson: The influence of conjugated estrogens in radioimmunoassays using different antibodies against estradiol-17 $\beta$. Steroids 1973, 22, 891-894.

Bosu, W. T., L.-E. Edquist, P. Lindberg, K. Martinsson \& E. D. B. Johansson: The effect of various dosages of lynestrenol on plasma levels of oestrogen and progesterone during the menstrual cycle in rhesus monkey. Contraception 1976, 13, 677-684.

Buttle, H. L. \& J. L. Hancock: The control of ovulation in the sow. J. Reprod. Fert. 1967, 14, 485-487.

Carpenter, L. S. \& L. L. Anderson: Pulsatile infusion of gonadotropin releasing-hormone on luteinizing hormone secretion and ovarian function in prepubertal gilts. J. Anim. Sci. 1981, 53, suppl. 1, 301 , abstr. 436. 
Chakraborty, P. K., J. J. Reeves, A. Arimura \& A. V. Schally: Serum LH levels in prepubertal female pigs chronically treated with synthetic luteinizing hormone-releasing hormone/follicle stimulating hormone-releasing hormone (LH-RH/FSH-RH). Endocrinology $1973,92,55-61$.

Dial, G. D., O. K. Dial, G. W. Bevier, S. D. Glenin \& P.J.Dziuk: Estrous behavior and circadian discharge of luteinizing hormone in prepubertal gilt in response to exogenous estrogen. Biol. Reprod. 1983, 29, 1047-1056.

Fleming, M. W. \& R. A. Dailey: Maturational changes in the induced, phasic release of luteinizing hormone $(\mathrm{LH})$ in prepubertal gilts. J. Anim. Sci. 1982, 55, suppl. 1, 351, abstr. 577.

Foxcroft, G. R., D. K. Pomerantz \& A. V. Nalbandov: Effects of estradiol-17 $\beta$ on LH-RH/FSH-RH-induced, and spontaneous LHrelease in prepubertal female pigs. Endocrinology 1975, 96, $551-557$.

Guthrie, H.: Induction of ovulation and fertility in prepubertal gilts. J. Anim. Sci. 1977, 45, 1360-1367.

Karlbom, I., S. Einarsson \& L.-E. Edqvist: Attainment of puberty in female pigs: Clinical appearance and patterns of progesterone, oestradiol-17 $\beta$ and LH. Anim. Reprod. Sci. 1982, 4, 301-312.

Kunavongkrit, A., H. Kindahl \& A. Madej: Clinical and endocrinological studies in primiparous zero-weaned sows. Zbl. Vet. Med. A, $1983,30,616-624$.

Lutz, J. B., G. B. Rampacek, R. R. Kraeling \& C. A. Pinkert: Serum luteinizing hormone and estrogen profiles before puberty in the gilt. J. Anim. Sci. 1984, 58, 686-691.

Lutz, J. B., G. B. Rampacek \& R. R. Kraeling: Induction of ovulation in the prepubertal gilt by pulsatile administration of gonadotropin releasing hormone. Domestic Animal Endocrinology $1985,2,61-65$.

Pomerantz, D. K., G. R. Foxcroft \& A. V. Nalbandov: Acute and chronic estradiol-17 $\beta$ inhibition of $\mathrm{LH}$ release in prepubertal female pigs: Time course and site of action. Endocrinology 1975, 96, $558-563$.

Schally, A. V., R. M. G. Nair, T. W. Redding \& A. Arimura: Isolation of the luteinizing hormone and follicle stimulating hormonereleasing hormone from porcine hypothalami. J. Biol. Chem. 1971, 246, 7230—7236.

Stupnicki, R. \& A. Madej: Radioimmunoassay of LH in blood plasma of farm animals. Endokrinologie 1976, 68, 6-13.

Trout, W. E., M. A. Diekman, J. R. Parfet \& G. E. Moss: Pituitary responsiveness to GnRH, hypothalamic content of $\mathrm{GnRH}$ and pituitary LH and FSH concentrations immediately preceding puberty in gilts. J. Anim. Sci. 1984, 58, 1423-1431.

Wildt, D. E., S. Fujimoto, J. L. Spencer \& W. R. Dukelow: Direct ovarian observation in the pig by means of laparoscopy. J. Reprod. Fert. 1973, 35, 541-543. 


\section{SAMMANFATTNING}

Plasmanivåerna av luteiniserande hormon efter olika doseringar av ett syntetiskt gonadotropin-releasing hormon hos prepubertala gyltor.

Målsättningen med denna undersökning var att studera frisättningen av LH, efter injektion av olika doser av GnRH, hos prepubertala gyltor. Fyra korsningsgyltor, 128-134 dagar gamla och med en kroppsvikt av 57-63 kg, användes i försöket. Fyra olika doseringar av GnRH - 0, 5, 25 respektive $125 \mu \mathrm{g}$ enligt "latin square design" injicerades via en permanent jugular-venkateter. Varje behandling omfattade tre injektioner givna med 90 minuters intervall. Upprepade blodprover togs under tidsperioden 90 minuter före första injektionen till 90 minuter efter tredje injektionen. LH-svaret redovisas som ytan under LH-kurvan från en baslinje uträknad med ledning av LH-nivån före GnRH-behandlingen. Ett positivt samband påvisades mellan GnRH-dosen och LH-svaret hos samtliga djur och behandlingstillfällen med ett enda undantag. Vid detta tillfälle var östradiol-17 $\beta$ nivån i blodet hög. Resultaten av denna studie visar att hypofysens LH-frisättning är relaterad till mängden injicerat GnRH hos prepubertala gyltor.

(Received February 24, 1986).

Reprints may be requested from: S. Rojanasthien, the Department of Obstetrics and Gynaecology, Faculty of Veterinary Medicine, Swedish University of Agricultural Sciences, S-750 07 Uppsala, Sweden. 